\title{
GLI3 Gene
}

National Cancer Institute

\section{Source}

National Cancer Institute. GL13 Gene. NCI Thesaurus. Code C18452.

This gene plays a regulatory role in limb development and is involved in sonic hedgehog signal transduction. 